\title{
Human Capacities for the Digital Economy in Russian Regions
}

\author{
L.V. Sankova \\ Departmevt of Economics of Labour and Indastrial \\ Complexes \\ Yuri Gagarin State Technical University of Saratov \\ Saratov, Russia \\ 1san@mail.ru \\ L.A. Otstavnova \\ Departmevt of Economics of Labour and Indastrial \\ Complexes \\ Yuri Gagarin State Technical University of Saratov \\ Saratov, Russia \\ liliotstav69@yandex.ru
}

\author{
E.V. Yanchenko \\ Departmevt of Economics of Labour and Indastrial \\ Complexes \\ Yuri Gagarin State Technical University of Saratov \\ Saratov, Russia \\ lucky2007ye@yandex.ru \\ N.A. Ivanova \\ Departmevt of Economics of Labour and Indastrial \\ Complexes \\ Yuri Gagarin State Technical University of Saratov \\ Saratov, Russia \\ nata_naiv@mail.ru
}

\begin{abstract}
The importance and topicality of the research is determined by the necessity to estimate the processes related with creation and development of human capacities required for digitalization of the economy on the federal and regional levels. The aim of the article is to investigate the current status and trends in the development of human resources for the digital economy in the regions based on the grouping method. The analysis is focused on the issues concerned with measuring "digital" parameters of human capacity and identifying its regional "profiles". The article considers possibilities for the development of new employment formats and risks associated with new "inequality in the labour force in the digital sector" of the regions. The given research highlights the groups of Russian regions which are distinguished for various labour force parameters in the digital economy. The investigation results can be applied in monitoring the regional profiles of digitalization and employment, identification of intergroup transitions, and interpretation of the changes in employment patterns in the regions with account for the new requirements.
\end{abstract}

Keywords: digital economy, human resources, labour market, employment, competencies, IT specialists

\section{INTRODUCTION}

As a global trend of the present-day development, digitalization of the economy requires both the relevant material and technical resources and human capacities which can spur the existing resources, and in the end ensure competitive advantages of the digital goods and services in the country. The existing potential of human resources, of the education system, migration processes, production specialization of regional enterprises, their incorporation into global digitalization chains, and various consumption patterns result in the varying effects of digitization of the economy in the Russian regions in terms of its rate and formats. These factors facilitate improvements in the existing disproportion in employment and development of human resources, and set out the points to quantify the impact of digitalization.

The aims related with the strategy to achieve the digitization plans in the regions can be realized through incorporation of digital innovations, which, in its turn, is closely interconnected with the processes, such as development and effective utilization of human resources. Consequently, there is a need to estimate the processes associated with development of human resources for the digital economy on the federal and regional levels, identify the challenges and work out the measures to encourage their growth and effectiveness.

\section{Literature REVIEW AND RESEARCH METHODOLOGY}

In the research papers devoted to the problems of human resource development for the digital economy, the focus is placed on the following key trends: research into digital transformation of socio-economic systems; digitization risks and digitization benefits for the labor markets, job creation, and business models of companies; direct ICT influence on the labor process, and latest requirements as to the competencies of staff members, etc.

Digital economy has become the subject of both interdisciplinary research and research in the field of economics in the recent years, whereas the term 'digital 
economic system and incorporation of digital technologies in most business areas [17, p.16]; [18, p.15].

A detailed analysis of the terminology used by foreign scientists in various aspects of conceptualization of the given concept is presented in the work by R. Bucht and R. Hicks [19, p. 148-151]. All the latest definitions emphasize the relationship and interdependence of economic relations and digitalization processes

Based on the works by J. Gray, B. Rump [20], and V. Arthur [21], we define digitalization of the economy as the process of development and incorporation of innovative digital technologies into economic activity, that is accompanied by creation of certain legal, organizational, socio-economic and other conditions, and which spreads across the various areas of Russian society.

Despite the various views on the sources and the influence rate on economic development, the researchers assume that the qualitative and quantitative parameters of human capacities play a significant role in gaining more from digitization's effects and promotion of information and communication technologies into present-day business practices.

Theoretical and methodological framework of research into transformation of human capacities under digitization's economic and social impact are inseparable from the concepts of the digital economy, information society and the knowledge economy, since they are characterized by optimization of the role of human factors related with knowledge, education, information and ability to use these elements.

Primary attention is placed on the development of human resources for the needs of the digital economy in the documents of the Federal project "Personnel for the Digital Economy" which is part of the Federal programme "Digital Economy in the Russian Federation". The focus is made on teaching the relevant competencies (270 thousand people, including heads of organizations and representatives of executive authorities); including online programmes aimed to boost digital literacy (10 million people).

In their papers the researchers define human resources / capacities as the manpower population [22, p.108]; multiple human abilities and opportunities to produce material benefits [23. p.253]; qualitative and quantitative characteristics of staff members [24. p.6].

Currently, the concept "human resources" is commonly used in the meaning of human factor that replaces the concepts of manpower and labor force. Thus, the point is made of professional and labor experience and skills, as well as sociocultural features, personal integrity, communicative and emotional potential, and their relevance for the labour activity. For example, in their work [25] A. Malinin and A. Andreeva consider human capacities as a resource of human capital, and transformation of human capacity into the human capital if the skills and competencies of a worker are in demand on the labor market [25, p.31].

In this paper we will interpret the human capacities as the competences of workers demonstrated in creating the added advanced way of production within the existing post-industrial economy, which is the outcome of digitalization of the socio- 
value using the digital, information and communication technologies.

The majority of the researchers in Russia place an emphasis on the role of human capacities demonstrated in the process of digitalization of economic system. However, the barriers in the course of transition to a new employment pattern under the digitalization conditions, the quantitative analysis and assessment of the human capacities in different regions requires a more detailed consideration.

The authors of the given paper hypothesize that the various regions in Russia differ significantly by certain parameters of human capacity, which determines the level of digitization of the economy in these regions.

For the methodological framework of the study, we applied the general scientific and special (economic and mathematical) methods. To estimate the human capacities of the regions, we used the analytical method, the comparative analysis method, and the methods of statistical analysis. Defining the homogeneous groups in the regions according to the parameters of human capacity of the digital economy implies the clustering of the regions by a set of parameters. The choice of the criteria is based on the analytical experience.

The following indicators were chosen as the basis for the study: a) the costs for training the staff members connected with the ICT development and application (rubles /per one staff member); this indicator determines contribution of companies into development of human resources with account for the digital element); b) the number of personal computers per 100 employees (pcs.); availability of these facilities to the staff members which allows them to perform "the digitization functions"; c) utilization of personal computers and the Internet resources at home (percentage of households); availability of a certain database that facilitates the development of digital competencies on the level of the household sector.

We recognize the importance of other indicators which indirectly reflect the problems with human resources in the digital economy; however, we selected the above mentioned indicators. For the calculation purposes, we used the normalized values of the selected indicators and the K-means method. Certain autonomous districts in Tyumen and Arkhangelsk regions were not included (we took into account the corresponding indicators by regions with account for the districts). Then, the clustering results were compared with the grouping of the by the indicator of IT specialists and other specific indicators characterizing the human resource component of the digital economy.

For the empirical basis of the study we used the Rosstat data (as of 2017) that are provided on the official website of the Federal State Statistics Service of the Russian Federation, including the data of the first rating "Staff Training for the IT industry in the Regions".

\section{RESULTS}

As a result of analysis based on the 2017 data, we identified five clusters with the regions characterized by the various patterns of contribution of companies and households into development and maintenance of the human capacities for the digital economy. Then, the given results were compared with the grouping of regions by the number of IT graduates in the regions in 2017. Let us make a more detailed analysis of the obtained clusters (see Table I). The city of Moscow is far ahead compared to the other regions in terms of the indicated parameters; therefore, this entity of the Russian Federation should be considered separately.

The first regional cluster is characterized by an average level of costs required for training the staff members the skills related with ICT development and application; average number of personal computers per 100 workers and above average are indicators demonstrating the use of personal computers and the Internet by households.

The regions of the second cluster are characterized for the highest rates in the number of personal computers per 100 workers; above average rates of the households provided with PCs and the Internet, and low rate of expenditures for ICT courses organized to train employees.

The third cluster includes the regions with the highest rate of households provided with PCs and the Internet; higher than average rate of company costs aimed to develop human resources, below the average rate of employees provided with personal computers. Meanwhile, the top rates of population (92\%) using the Internet were observed in 2017 in the Moscow Region and the Republic of Tatarstan.

The 4th cluster includes the regions with basically average rates of households having PCs and access to the Internet, as well as the rate of employees with personal computers; meanwhile, (similar to the second group) the rate of the companies' expenses for employee ICT training courses is low.

The fifth cluster includes the regions with the minimal company expenditures for training staff members the ICT skills; below average rate of workers provided with personal computers, and average rate of households with PCs and the Internet access. It should be noted that the Chechen Republic "falls out" of cluster 5 (due to a low rate of households provided with PCs). This is accounted for by the low income of the population and high costs required for the Internet connection. In the Chechen Republic, the rate of population using the Internet is $69.3 \%$, which is the lowest across Russia. 
TABLE I. CONSTITUENTS OF THE REGIONAL CLUSTERS

\begin{tabular}{|c|c|c|}
\hline $\begin{array}{c}\text { Cluste } \\
\mathbf{r}\end{array}$ & $\begin{array}{c}\text { Number } \\
\text { of regions }\end{array}$ & Constituients \\
\hline 1 & 4 & $\begin{array}{l}\text { Kaluga, Murmansk, Astrakhan and Sverdlovsk } \\
\text { Regions }\end{array}$ \\
\hline 2 & 11 & $\begin{array}{l}\text { Republic of Karelia, St. Petersburg, Republic } \\
\text { of Kalmykia, Altai Republic, Kamchatka } \\
\text { Territory, Khabarovsk Territory, Kaliningrad, } \\
\text { Novosibirsk, Tomsk, Magadan and Sakhalin } \\
\text { Regions }\end{array}$ \\
\hline 3 & 2 & $\begin{array}{l}\text { Moscow Region, and Tyumen Region } \\
\text { including the districts }\end{array}$ \\
\hline 4 & 26 & $\begin{array}{l}\text { Sevastopol City, Voronezh, Ivanovo, } \\
\text { Kostroma, Oryol, Ryazan, Tambov, Tver, } \\
\text { Kirov, Nizhny Novgorod, Penza, Yaroslavl, } \\
\text { Vologda, Omsk, Samara, Saratov, Novgorod, } \\
\text { Chelyabinsk, Volgograd, and Rostov Regions; } \\
\text { Komi Republic; Arkhangelsk Region including } \\
\text { the districts; Stavropol, Primorsky, } \\
\text { Krasnoyarsk and Perm Territories; Republic of } \\
\text { Bashkortostan, Republic of Tatarstan, Udmurt } \\
\text { Republic, Chuvash Republic, Republic of } \\
\text { Buryatia, Republic of Tiva, Republic of } \\
\text { Khakassia, Republic of Sakha (Yakutia), } \\
\text { Jewish Autonomous Region, and Chukotka } \\
\text { Autonomous Region }\end{array}$ \\
\hline 5 & 28 & $\begin{array}{l}\text { Belgorod, Bryansk, Vladimir, Kursk, Lipetsk, } \\
\text { Smolensk, Tula, Leningrad, Pskov, Orenburg, } \\
\text { Ulyanovsk, Kurgan, Irkutsk, Kemerovo and } \\
\text { Amur regions; Republic of Adygea, Republic } \\
\text { of Crimea, Krasnodar Territory, Republic of } \\
\text { Dagestan, Republic of Ingushetia, Kabardino- } \\
\text { Balkar Republic, Karachaievo-Cherkess } \\
\text { Republic, Republic of North Ossetia-Alania, } \\
\text { Chechen Republic, Republic of Mari El, } \\
\text { Republic of Mordovia, Altai Territory, and } \\
\text { Trans-Baikal Territory }\end{array}$ \\
\hline
\end{tabular}

\section{DISCUSSION}

Analysis of the cluster constituents within the period under review allows us to conclude the following:

1) The first cluster is smallest in number; it includes the regions with an average rate of costs and the number of PCs per 100 employees, while the rate of households provided with $\mathrm{PCs}$ and the Internet is above average.

2) In the majority of cases, the high rates related referred to one parameter correlate with the low rates of the other parameters; otherwise, we observe significant deviations by one or a couple of parameters;

3) The biggest in number are the 3-rd and the 4-th clusters characterized by an average rate in the number of personal computers per 100 employees, but significantly differing in expenditures for ICT courses required for staff training; the rate of the households with PCs and the Internet access is at average. The number of population using the Internet in half of the regions of the Russian Federation ranges from 80 to $92.8 \%$. In 31 regions this indicator was lower, ranging from $70-80 \%$. Among the leaders relating the given parameter are such regions as St. Petersburg, Chukotka Autonomous District, Moscow, Tyumen, Murmansk, and Samara Regions, and Sevastopol City. Beside the Chechen Republic, among those regions lagging behind should be pointed out Oryol, Ulyanovsk, and Ryazan Regions, and the Chuvash Republic.

The analysis showed that the main reasons for "no access" to the Internet in the households are: 1) reluctance to use the Internet (more than 70\%) (Fig. 1), and 2) lack of the skills. Moreover, the biggest number of households hesitant about using the Internet is observed in the Urals Federal District, whereas the smallest number is revealed in the Central District. Lack of technical facilities is mainly characteristic for the North Caucasus and Far Eastern Federal Districts. Regarding lack of the skills parameter, the biggest rate is found in the Volga Federal District.

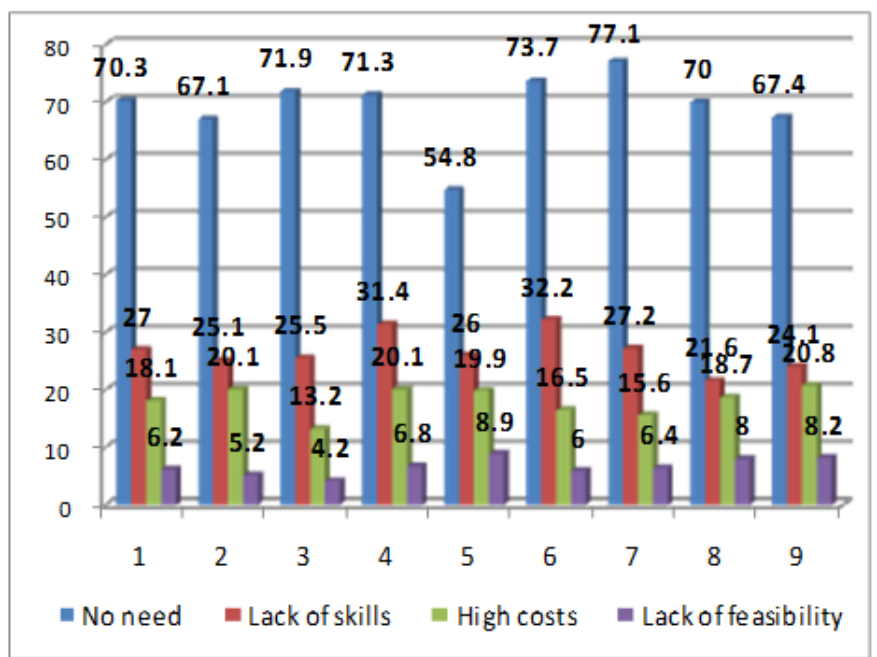

Fig. 1. Reasons for not using the Internet in the households of the federal districts of the Russian Federation (by percentage from the number of households without the Internet access) (1- The Russian Federation, 2 Central Federal District, 3 - northwestern federal district, 4 - Southern Federal District, 5 - North Caucasian Federal District, 6 - Volga Federal District, 7 Ural federal district, 8 - Siberian Federal District, 9 - Far Eastern Federal District)

An in-depth analysis shows that such regions as the Republic of Dagestan, the City of Sevastopol, the Republic of Buryatia, and Tomsk Region are characterized by the smallest rate of organizations using the Internet (from $68.4 \%$ to $75 \%$ ). In more than a one-third of the regions, the rate of organizations using the Internet ranged from $92.6 \%$ to $100 \%$. Among the leaders are the Republic of Ingushetia and the Republic of Crimea.

For a comprehensive assessment of human capacities, the authors analyzed the number of trained ICT specialists using the spatial criterion. We analyzed the education market in the regions of the Russian Federation by the rate of graduate specialists in the area of IT technologies, which allowed us to make the quantitative assessment of the opportunities and risks from introducing the digital economy, and analysis of the educational market in the regions of the Russian Federation by the rate graduate specialists in the field of IT technologies, which allowed us to conduct the quantitative assessment of the human capacities and risk related with development of human resources. As a result, we identified four groups by the parameter "ICT graduate specialists". 
significant number of universities and ICT graduate specialties.

In addition to the given factor, we observe the migration of ICT graduates to find the jobs in Moscow or St. Petersburg, where we observe the positive dynamics relating the demand for the given profession. Based on the analysis of the revealed groups, we can conclude that in addition to traditional measures used to regulate the educational market and the labor market in the regions, it is vital to implement special programs with account for the regional profiles.

The majority of ICT specialists are recorded in information and communication areas, process industries, research and engineering activities. Basically, $80 \%$ of ICT specialists are employees aged from 15 to 39 years.

Comparison of the revealed regional groupings shows that among the leaders in the number of IT graduates in 2017 are Rostov Region, Bashkortostan and Samara Region; these regions are characterized by the low companies' expenditures on training ICT employees and average rates of workers provided with PCs, and households with PCs and the Internet connection. The regions of the 3 rd group (with the number of ICT graduate specialists over 500), as a rule, are also referred to the 4th group.

Development of human resources for the digital economy particularly implies application to the possibilities and resources of regional universities that implement appropriate training programs. Table III presents the regions with the biggest number of universities that implement programs for ICT specialists.

TABLE III. 2017 LEADERS AMONG THE RUSSIAN FEDERATION REGIONS BY THE NUMBER OF UNIVERSITIES PROVIDING IT PROGRAMMES

\begin{tabular}{|l|l|l|}
\hline Group & \multicolumn{1}{|c|}{$\begin{array}{c}\text { Number of } \\
\text { universities }\end{array}$} & \multicolumn{1}{c|}{ Regions } \\
\hline 1 & Above 15 & $\begin{array}{l}\text { Moscow (Moscow Region) and St. } \\
\text { Petersburg }\end{array}$ \\
\hline 2 & Above 10 & $\begin{array}{l}\text { Regions: Rostov, Sverdlovsk, Samara, } \\
\text { Novosibirsk, Voronezh, Chelyabinsk }\end{array}$ \\
\hline 3 & Less than 10 & $\begin{array}{l}\text { Stavropol Territory, Perm Territory, } \\
\text { Krasnodar Territory. } \\
\text { Regions: Penza, Saratov, Volgograd, } \\
\text { Kaliningrad, Tomsk, Kursk, Bryansk } \\
\text { Far East, etc. }\end{array}$ \\
\hline 4 & Less than 5 & $\begin{array}{l}\text { Regions: Amur, Arkhangelsk, } \\
\text { Astrakhan, Volgograd, Vologda, } \\
\text { Tambov, Vladimir, Yaroslavl, Ivanovo, } \\
\text { Belgorod, Ulyanovsk, Kostroma, Pskov, } \\
\text { Tver, Kurgan, Trans-Baikal Territory, } \\
\text { Khabarovsk Territory, etc. }\end{array}$ \\
\hline & & \multicolumn{1}{|c}{} \\
\hline
\end{tabular}

It should be noted that high potential in training specialists for the digital economy is the key drive for the region's development. In 2017, by the proportion of qualified staff working in the area of digital economy, among the leaders were the City of Moscow (2.9\%), Chukotka Autonomous Region (2.3\%), Moscow and Tomsk Regions (1.7\%). The average proportion across the Russian Federation is at 1.2, while in such regions as Sakhalin, Novgorod, Volgograd, and 
Assessment of human capacities of the digital economy is Saratov it equals 0.4. To compare, this indicator in Finland and Sweden is at 3.4.

The obtained results confirm the conclusion about nonuniformity of the regions in terms of the parameters related with the development of human resources, and the start-up positions in digital development. Within the regional groups, the differing rates in the development of digital economy technologies will determine the strategy associated with unemployment risks and the qualifying digital divide. Lack of employment guarantees will become common primarily in the areas which benefited from their digitization gains; these areas include logistics and transport, office services and administration, production, sales, etc.

According to the 2017 ranking of the constituent entities of the Russian Federation, among the leaders with emerging digitized economies were Moscow, St. Petersburg, Tatarstan, Khanty-Mansiysk Autonomous District -Yugra, Tyumen Region, Yamalo-Nenets Autonomous District, Moscow Region, Bashkortostan, Leningrad, and Chelyabinsk Regions. Moreover, the gap between the federal districts by these indicators is lower than the gap within the federal districts. In the grouping we presented, these regions are included in various groups.

Our research shows that the regions are involved in various digitalization programs differing by scale and content - starting from large-scale programs to certain regional acts on establishment of the work groups engaged in driving digitalization, decrees by heads of the district administration on creating technology parks, and decrees on reducing the gap in providing digital services to the population. We might agree with researchers highlighting the following key problems associated with inequality in digitization on the regional levels: lack of qualified staff and funding, and gradual development of the relevant regulatory environment.

The typology we have designed will be a notable addition to the existing typologies (developed in line with the socioeconomic criteria of digitalization), which creates a comprehensive and multidimensional picture of the asymmetry in the regional economic and digital space in Russia. In the future, it would be reasonable to compare the obtained results with clustering results by the parameters of "digital employment" platforms in the regions.

The authors [15, p.19] rightly remark that defining the points of sustainable economic growth in the regions implies not only digital transformation of the regional economy under modern conditions, but above all, prioritized development of human resources as a source of capital to drive economic growth and innovation development.

\section{CONCLUSION}

The digital economy creates an enormous potential beneficial for economic development of the regions. The Internet creates significant benefits and speeds up activities on the existing market of goods, services and labour in the regions, but it can also generate the existing asymmetry in the development of human resources within these areas. a systemic problem comprising estimation of the potential of educational systems in the regions, the migration mobility of ICT specialists, the existing potential of households in developing supply and demand in the employment market, "incorporation" of business structures in training employees the relevant skills using ICT technologies, training the population specific skills using PCs with appropriate programs, financing activities aimed to develop human resources for the digital economy, etc. This paper deals with only a certain segment of the problem and defines vectors for further research.

The proposed approach to grouping the regions by the parameters of human capacities for digital economy allows for estimating the situation in terms of development of IT capacities, identifying the key factors in driving digitization on the regional level, and substantiating effective policies for the regional groups. The system of human capacity parameters should be analyzed in close connection with the strategies of "digital" development in the regions. Altogether, we should emphasize the necessity for creating methodological tools to estimate the new phenomena, and significant expansion of the database, primarily on the regional level.

Our further research will be associated with new methodology and approaches to assessing effectiveness of human capacities for the digital economy, and bridging the digital gaps in the competencies; revealing interconnection and interdependence of the digital element and productivity growth in the regions; developing measures to reduce excessive asymmetry in "digital" development and living standards in the $\mathrm{n}$ regions; expanding new employment formats and ensuring social security in the regions; evaluating effectiveness of the regional state policy in improving efficiency of human resources for the digital economy in the regions.

\section{REFERENCES}

[1] N. Negroponte, "Bits \& Atoms". New York: Knopf, 1995.

[2] D. Tapscott, "The Digital Economy: Promise and Peril In The Age of Networked Intelligence", McGraw-Hill, 1995.

[3] T. L. Mesenbourg, "Measuring the Digital Economy“". U.S. Bureau of the Census, 2001. Available at: https://www.census.gov/library/workingpapers/2001/econ/mesenbourg-01.html (accessed: 12.11.2018).

[4] C. Dahlman \& Sam Mealy \& Martin Wermelinger, 2016. "Harnessing the digital economy for developing countries, "OECD Development Centre Working Papers 334, OECD Publishing. Available at: https://ideas.repec.org/p/oec/devaaa/334-en.html (accessed: 29.10.2019).

[5] E. Brynjolfsson \& B. Kahin, "Understanding the Digital Economy Data, Tools, And Research". Cambridge, MA, MIT Press, 2000.

[6] G. Myovella, M. Karacuka, J. Haucap, "Digitalization and economic growth: A comparative analysis of Sub-Saharan Africa and OECD economies", Telecommunications Policy Available online, 26 September 2019, 101856, in press.

[7] C. Watanabe, Y. Tou, P. Neittaanmäki, "A new paradox of the digital economy - Structural sources of the limitation of GDP statistics" , Technology in Society, vol. 55, November 2018, pp. 9-23.

[8] G. Mertai Kyzy Berdykulova, A. Ismagul UlySailov, S. Ydyrysh Kyzy Kaliazhdarova, E. Baglan Uly Berdykulov, "The Emerging Digital Economy: Case of Kazakhstan", Procedia - Social and Behavioral Sciences, vol. 109, 8 January 2014, pp. 1287-1291. 
[17] M. V. Kosolapova, V. A. Svobodin, "Methodological issues of systemdigital economy-interrelation of system and digital economies", Soft measurements and calculations, vol. 6 (19), 2019, pp. 13-16. Research Policy, vol. 47, Issue 8, October 2018, pp. 1367-1387.

[10] M. Mäntymäki, A, Baiyere, A.K.M NajmulIslam, "Digital platforms and the changing nature of physical work: Insights from ride-hailing", International Journal of Information Management, vol. 49, December 2019, pp. 452-460.

[11] W. D. Holford, "The future of human creative knowledge work within the digital economy”, Futures, vol. 105, January 2019, pp. 143-154.

[12] E. K. Karpunina, Th. Gorchev, M. A. Stromova, "Virtual space of economic entities: the myth of the digital economy or the object of project management?", Socio-economic phenomena and processes, vol. 6, 2017, pp. 112-118.

[13] World Bank world development report 2016 "Digital dividends". Available https://openknowledge.worldbank.org/bitstream/handle/10986/23347/21 0671RuSum.pdf (accessed: 29.10.2019).

[14] Digital Single Market: bringing down barriers to unlock online opportunities, The European Commission. Available at: https://ec.europa.eu/commission/priorities/digital-single-market_en (accessed: 29.10.2019).

[15] D. D. Burkaltseva, D. G. Kosten, Yu. N. Vorobiev, "Formation of digital economy in Russia: essence, features, technical normalization, problems of development", Scientific and technical Vedomosti of St. Petersburg state Polytechnic University. Economics, vol. 3, 2017, pp. 925.

[16] D.M. Zozulya, "Digitalization of the Russian economy. Industry 4.0: challenges and prospects", Questions of innovative economy, vol. 1, 2018, pp. 1-14.

[18] M. V. Popov, A. M. Sukhorukova, "Personnel potential in the implementation of the program "Digital economy of the Russian Federation", Vestnik of SSSEU, vol.4(73), 2018, pp. 15-21.

[19] R. Buch, R. Hicks, "Definition, concept and measurement of the digital economy", Bulletin of international organizations, vol.2, 2018. pp.148162.

[20] J. Gray, B. Rumpe, "Models for digitalization", Soft \& Systems Modeling, vol. 14, iss. 4, 2015, pp. 1319-1320.

[21] W. B. Arthur, "The second economy”, McKinsey Quarterly, iss.4, 2011, pp. 90-99.

[22] I. I. Tsvetkova, A.V. Sivolap, "Personnel potential as an elemeny of enterprise educational potential", Economics and management, vol. 6, 2007, pp.106-109.

[23] A.A. Pidkova, N. A. Podgornaya, "Determining the place of personnel potential in the system of economic potential components of an industrial enterprise" in Directions of improving the efficiency of management activities of state authorities and local self-government [Digests 1st Int. Conf., Russia, p. 250-254, 2018.].

[24] I. S. Yaruskin, "Personnel potential of the enterprise and ways of improvement of personnel potential at the enterprise", Tendencies of development of science and education, vol. 2, 2015, pp.4-6.

[25] A.M. Malinin, A.D. Andreyeva, "Regional Laboure Market: Transformation of Human Potential, Laboure Potential and Human Capital", Components of Scientific and Technological Progress, vol.1 (31), 2017, pp. 30-34 